\title{
Hashimoto's disease as a risk factor for developing papillary thyroid cancer
}

\author{
Katarzyna Banaszczyk ${ }^{1}$ \\ Collegium Medicum w Bydgoszczy, UMK w Toruniu Wydział Lekarski, Polska
}

Banaszczyk K. Hashimoto's disease as a risk factor for developing papillary thyroid cancer. Med Og Nauk Zdr. 2019; 25(1): 12-15. doi: $10.26444 /$ monz/103590

\begin{abstract}
Introduction. Already in 1955, Hashimoto disease, which is the most common autoimmune disease, was associated with the most common thyroid cancer - papillary thyroid cancer (PTC). Despite the passage of years and many intensive scientific studies on the relationship between these two diseases, the mechanism and the basis on which Hashimoto's disease predisposes to PTC has still not been established.

Objective. The aim of the study is to summarize the current state of knowledge on mechanisms by which HT may predispose to the development of PTC, and present the latest clinical trials confirming that HT is a risk factor for PTC, and describe its possible impact on the course of the disease.

Brief description of the state of knowledge. The study concerns the inflammatory, immunological and genetic mechanisms that may be significantly related to the predisposition of HT patients to the development of PTC. Recent studies have shown that the RET / PTC oncogene or p63 protein can combine HT with PTC development. This study also presents the results of clinical trials regarding the comparison of the prevalence of PTC in patients with HT, and in patients without autoimmune thyroid disease.

Summary. There is a need for further scientific research through which more will be leant about the mechanisms linking HT and PTC. Vigilance should be maintained while caring for a patient with HT, as many scientific studies confirm the more frequent occurrence of PTC in patients afflicted with autoimmune thyroiditis. HT can also have a significant impact on the course of cancer and its prognosis.
\end{abstract}

\section{Key words}

Hashimoto's disease, tumour, papillary thyroid cancer

\section{INTRODUCTION}

Hashimoto's disease (Hashimoto's thyroiditis - HT), otherwise known as chronic autoimmune thyroiditis, is the most common autoimmune disease, and the most common cause of hypothyroidism in areas where iodine intake is normal [1]. The prevalence of Hashimoto's disease worldwide is about $0.3-1.5$ cases per 1,000 people per year [2]. Hashimoto's disease was first described in 1912 by the Japanese surgeon Hakaru Hashimoto. In his work, he presented four patients with thyroid dysfunctions, which he called lymphatic goitre (stream lymphomatosa) [3]. HT is associated with various degrees of hypothyroidism due to an autoimmune reaction directed against thyroid cells. Antibodies against thyroid antigens - against thyroid peroxidase and against thyroglobulin - take part in this process. It is believed that the cause of HT is a combination of genetic susceptibility and environmental factors [4]. $\mathrm{HT}$ is much more common in women, the ratio varies in publications from 5:1 to 20:1 [5].

Papillary thyroid carcinoma (PTC) is the most common thyroid cancer and accounts for $80-90 \%$ of all such cancers [6]. It can occur at any age, including among children, but most patients are 20-50 years old when they become ill. The ratio of women to men is about 4:1. PTC is most often manifested as a single lump or a clear lump in the thyroid nodular goitre. Some patients have enlarged cervical lymph

Adres do korespondencji: Adreess for correspondence: Katarzyna Banaszczyk, Collegium Medicum w Bydgoszczy, UMK w Toruniu Wydział Lekarski, Polska E-mail: kbanaszczyk570@gmail.com

Received: 2 November 2018; Accepted: 1 February 2019 nodes due to a metastatic tumour [7]. PTC is a cancer with a very good prognosis and a slow clinical course. The risk of relapse is around $12 \%$ [8].

In 1955, Dailey et al. were the first to suggest a relationship between Hashimoto's disease and PTC, combining chronic thyroid inflammation with neoplastic lesions [9]. Nevertheless, until today, the relationship between HT and PTC has not been clearly explained; however, there is an increase in the number of clinical trials in the medical literature confirming that HT can be a direct and independent risk factor for the development of papillary thyroid cancer. Bearing in mind the fact that Hashimoto's disease is an increasingly common problem in our country, it is worth looking into the matter of its relationship with a potentially serious disease entity - papillary cancer of the thyroid gland. In this case, it is worth keeping oncological vigilance in the case of a patient with Hashimoto's disease. This case should therefore be close not only to specialists in endocrinology, but also to family physicians who have patients under their care with autoimmune hypothyroidism.

The aim of this study is to present and summarize research carried out in recent years which indicate the relationship between HT and thyroid papillary cancer development, and suggest that HT can be considered as a risk factor for PTC development. Furthermore, this study also applies to the currently known mechanisms linking HT with the development of PTC.

Hashimoto's disease and papillary carcinoma thyroid in terms of histopathology. In Hashimoto's disease, the thyroid gland is usually evenly enlarged in macroscopic terms, but 
there are cases where only the local enlargement of the organ occurs. Papillary cancer causes a typical focal enlargement; however, its multifocal occurrence is also possible, which increases the size of the entire organ. The cross-sectional area in Hashimoto's disease is pale, grey, slightly fragile, and in papillary cancer it is granular. The most characteristic microscopic feature in Hashimoto's disease is the presence of atrophic thyroid follicles, pancreatic infiltration from mononuclear cells (lymphocytes, plasmocytes) and the presence of Hürtl cells (cells with abundant, granular cytoplasm). The typical features of papillary carcinoma its include the presence of cells whose nuclei contain evenly dispersed chromatin, which gives the appearance of frosted glass (the so-called "eyes of an orphan Ann"). In addition, there are intramyucleic inclusions, i.e. cytoplasmic inclusions and calcifications in the warts, called sand bodies [10]. The above features distinguish the disease entities described.

A study was also carried out which indicated that papillary cancers diagnosed against Hashimoto's disease often show significant desmoplasia of the stroma and a pseudo-spatial pattern. The diagnosis of characteristic cytological features of thyroid papillary carcinoma may be hampered by significant tumour obliteration resulting from organ fibrosis in the course of Hashimoto's disease. [11].

Hashimoto's disease and papillary carcinoma thyroid in ultrasound. Check-up studies of Hashimoto's disease are needed and are important because of the increased risk of lymphomas and thyroid cancers in patients with autoimmune thyroid disease. The ultrasound image of Hashimoto's disease is characterized by a generally reduced echogenicity resulting from lymphocytic infiltrates, hyperechogenic echoes of the connective tissue stroma. The organism's echo structure may be heterogeneous, obliterated, and moreover, hypoechoic areas may be visible. In the initial stages of the disease, the organ can be enlarged, but sometimes its volume is reduced. Initially, increased vascularity can also observe (observed thanks to the colour doppler). Over time, the vascularisation of the organ may be reduced, especially when the level of hormones is even. Other characteristics of Hashimoto's ultrasound image include the presence of uneven capsule contours and thickening of the isthmus. $[12,13]$ Papillary thyroid carcinoma, typically in the ultrasound image, is a solid, hypoechogenic, heterogeneous change, blurred in a limited way from the rest of the organ. Moreover, this change is usually centrally vascularised. It is possible that there is a characteristic acoustic shadow behind the change that is a papillary carcinoma, which makes it possible to distinguish between a solid change and a fluidone. For the malice of focal lesion, among others, it indicates a larger dimension of the AP than the parietal-cauda dimension. Microcalcyphication in papillary carcinoma can be seen in $25-90 \%$ of cases. $[14,15]$

Visualizing the focal lesion in the thyroid affected by Hashimoto's disease is not easy. The presence of hypoechoic areas in the course of Hashimoto's disease makes it difficult to notice a significant change in focal length, which in the case of papillary carcinoma of the thyroid gland is also usually hypoechogenic. Furthermore, the variable, increased vascularisation of the organ makes it difficult to evaluate the focal lesion's vascularity. Bearing in mind the above information, in the course of Hashimoto's disease, an accurate and careful thyroid testing technique is important in order not to overlook focal lesions.
Mechanisms combining Hashimoto's disease and papillary thyroid cancer. Exactly how Hashimoto's disease contributes to the development of papillary thyroid cancer has not yet been fully understood and explained. It is believed that chronic thyroiditis associated with Hashimoto's disease can lead to damage to the genetic material and genetic mutations that underlie the development of the malignant process. Participation in this process may have reactive oxygen species arising in the course of autoimmune thyroid disease [16]. A study was also conducted in which the presence of antibodies directed against thyroglobulin was found to be an independent risk factor for papillary thyroid cancer, which may suggest the involvement of immunological mechanisms in the development of cancer [17].

Another, genetic hypothesis concerning the relationship between HT and PTC is based on the rearrangement of the RET / PTC proto-oncogene. The rearrangement of the RET / PTC gene is highly specific for papillary thyroid cancer. The RET gene is located on the 10q11.2 chromosome and is a gene that codes for the tyrosine kinase receptor [18]. In many cases of Hashimoto's disease, this regrouped oncogene has been found in thyroid cells [19]. Wirtschafter et al. have described the expression of RET / PTC1 and RET / PTC3 oncogenes in patients with Hashimoto's disease [20]. The hypothesis associated with this oncogene was confirmed by Arif et al. who showed that both these diseases are characterized by similar immunohistological traits in the field of staining, and moreover, they have a similar molecular profile with regard to RET / PTC gene rearrangements [21].

The expression of $\mathrm{p} 63$ protein is also common for papillary carcinoma and Hashimoto's disease, and it is possible that the expression of the $\mathrm{p} 63$ protein may be a potential pathological link between these two disorders. This protein is not present in normal thyroid tissue, Graves' disease or other thyroid tumours. Research suggests that both disorders may be initiated by the same population of pluripotent p63-positive stem cells $[22,23]$. None of the above-hypotheses regarding the relationship of HT to PTC has yet been confirmed; more research is therefore still needed to explain exactly how HT can contribute to the development of papillary thyroid cancer.

\section{Hashimoto's disease as a risk factor for developing papillary papillary cancer - scientific reports from recent years. In} recent years, the relationship between Hashimoto's disease and papillary thyroid cancer has been a popular topic of scientific research for scientists worldwide.

In 2018, a retrospective study was published to determine the frequency of coexistence of Hashimoto's disease and thyroid cancer in patients after thyroidectomy. Researchers analyzed the clinical-histopathological data of 2,117 patients $(1,738$ women and 379 men), from 1 January 2005 - 31 December 2014. The focus was on the histological assessment of the gland, the presence of Hashimoto's disease, the presence of malignant lesions, and also on the assessment of multifocal, size and possible bilateral presence of the lesion. Thyroid cancer was detected in 318 cases, and microcarcinoma in 169 cases. Papillary thyroid cancer was the most common histological type - 62\% among cancers, and $94 \%$ among microcarcinomas. In the present study, coexistence of Hashimoto's disease and thyroid cancer was found in $18 \%$ of cases, moreover - in 58\% of casus, Hashimoto's disease coexistenced with thyroid microcarcinoma. The presence of 
thyroid cancer and HT did not affect the size of the tumour and did not affect its multifocal nature. Also, the more common bilateral incidence of the thyroid gland was observed in the presence of Hashimoto's disease $(\mathrm{p}=0.041)$, but this did not translate into bilateral thyroid cancer $(\mathrm{p}=0.731)$ [24]. This study shows that Hashimoto's disease is associated with a significantly increased risk of developing thyroid cancer, especially thyroid microcarcinoma. Considering the fact that the most frequently diagnosed cancer was papillary cancer, the study indicates that HT can be considered as a risk factor for PTC development.

Chinese scientists conducted a study which qualified 6,109 patients who underwent thyroidectomy in 2008-2010. Among them, 653 had been diagnosed with Hashimoto's disease. The incidence of papillary thyroid carcinoma was higher among patients with Hashimoto's disease (58.3\%, i.e. 381 of 653 who had identified thyroid papillary cancer), in patients without $\mathrm{HT}$, papillary carcinoma occurred less frequently $(2,416$ of 5,456 patients, i.e. $44.3 \%$ of patients without HT had a diagnosis cancer $\mathrm{p}<0.05)$. Co-morbidity of HT and PTC was also associated with a significantly elevated level of TSH. Researchers have hypothesized that long-term HT leads to elevated levels of serum TSH, which is a real risk factor for thyroid cancer. [25]

Another interesting study showing the relationship between Hashimoto's disease and papillary thyroid cancer was carried out by Polish scientists. This was a retrospective cohort study of 7,545 patients who had thyroidectomy performed in 2002-2010. In the analyzed group, 452 patients were identified who had diagnosed HT and 7,093 patients without autoimmune thyroid disease. In the group of patients with HT, 106 were diagnosed with papillary thyroid cancer, which is $23.5 \%$ of patients with HT. In the group of patients without autoimmune thyroid disease, papillary carcinoma occurred with a frequency of 7.5\% (530 people from 7,093). Both analyzed groups were characterized by a similar male to female ratio, and a similar average age of patients. The presence of metastases to the lymph nodes in the central compartment (VI interval) was also assessed. Such metastases were observed in 81 of 106 subjects, i.e. $76.4 \%$ of patients with coexisting HT and papillary thyroid cancer, and interestingly - only 121 out of 530 people, or $22.8 \%$ of patients with PTC without Hashimoto's disease. In this study, HT was associated with a threefold increase in the incidence of PTC, compared to other thyroid diseases, and the spread of PTC to the lymph nodes of compartment VI was four times more frequent in patients with HT than in non-HT patients [26]. Based on the above study, it can be concluded that Hashimo's disease is a risk factor for PTC, and is also associated with a greater spread of cancer to regional lymph nodes. Italian researchers reached similar conclusions. In a retrospective study, 462 patients who had thyroidectomy in 1995-2008 were analyzed histologically and clinically. After inclusion in the study, patients were divided into three groups. The first group $(n=69)$ were patients with diagnosed HT, the second group $(n=45)$ patients with non-specific thyroiditis or TIL (tumor-infiltrating lymphocytes), and the third group $(n=290)$ were patients without thyroiditis. The study showed that $36.2 \%$ of patients with HT had both PTC, and in the group without HT, the percentage of patients with diagnosed PTC was $22.6 \%$. This means that the presence of HT was associated with a 1.6-fold increase in PTC risk in this study. It was also noticed that PTC in the group of HT patients more frequently showed multifocal increase $(56 \%$ of tumour cases), compared to the group without HT, where this percentage was significantly lower - 26.32\%). [27] This suggests that Hashimoto's disease may predispose to the development of multiple papillary thyroid cancer foci.

In addition to studies confirming the hypothesis that Hashimoto's disease may be a risk factor for the development of papillary thyroid cancer, studies that denied this finding hale also been published. In several studies, there was no statistically significant relationship between Hashimoto's thyroiditis and papillary thyroid carcinoma. [28-30] However, it should be noted that the number of studiem negating a relationship between HT and PTC is definitely less than the articles confirming this hypothesis.

\section{SUMMARY}

Many scientific studies confirm a statistically significant relationship between Hashimoto's disease and papillary thyroid cancer. Many authors indicate that autoimmune thyroiditis may be a significant and direct risk factor for the development of this most common cancer of the thyroid organ. Some authors present opposite conclusions from their research in which this hypothesis is rejected. Nevertheless, the majoraty of studiem confirm a relationship between these two diseases, it is therefore worth continuing research on this subject and exploring the mechanisms that underlie this phenomenon. The incidence of autoimmune diseases, including Hashimoto's disease, is still increasing and the importance of this problem will also increase in the near future. It is worth expanding the knowledge on this subject among doctors caring for patients with Hashimoto's disease, in order that they will remain alert to oncology, and be attentive when diagnosing thyroid diseases.

\section{REFERENCES}

1. Chaker L, Bianco AC, Jonklaas J, Peeters RP. Hypothyroidism. Lancet. 2017. Volume 390. Issue 10101; 1550-1562. doi: 10.1016/S01406736(17)30703-1.

2.Latina A, Gullo D, Trimarchi F, Benvenga S. Hashimoto's thyroiditis: similar and dissimilar characteristics in neighboring areas. Possible implications for the epidemiology of thyroid cancer. PLoS ONE 2013. 8(3): e55450. doi: 10.1371/journal.pone.0055450.

3. Caturegli P, De Remigis A, Chuang K, Dembele M, Iwama A, Iwama S. Hashimoto's thyroiditis: celebrating the centennial through the lens of the Johns Hopkins hospital surgical pathology records. Thyroid 2013; 23: 142-150. doi: 10.1089/thy.2012.0554.

4. Tomer Y, Huber A. The etiology of autoimmune thyroid disease: a story of genes and environment. J Autoimmun. 2009; 32: 31-239. doi: 10.1016/j. jaut.2009.02.007.

5. Lal G, Clark OH. Textbook of endocrine surgery, Philadelphia: Saunders. 2005. Chronic Thyroiditis; pp. 38-40.

6. Chen W, Zheng R, Baade PD, Zhang S, Zeng H, Bray F, Jemal A, Yu XQ, He J. Cancer statistics in China, 2015. CA A Cancer J Clin. 2016; 66: 115-132. doi: 10.3322/caac.21338.

7. Cibas ES. Cytology. Chapter 10. Thyroid. 2014 by Saunders. Elsevier Inc; $267-297$.

8. Yuan J, Li J, Chen X, Lin X, Du J, Zhao G, Chen Z, Wu Z. Identification of risk factors of central lymph node metastasis and evaluation of the effect of prophylactic central neck dissection on migration of staging and risk stratification in patients with clinically node-negative papillary thyroid microcarcinoma. Bull. Canc. 2017; 104: 516-523. doi: 10.1016/j. bulcan.2017.03.005.

9. Dailey ME, Lindsay S, Skahen R. Relation of thyroid neoplasms to Hashimoto disease of the thyroid gland. AMA Arch Surg. 1955; 2: 291-7. 
10. Kumar V, Abbas AK, Aster JC. Robbins Basic Pathology, Elsiever, 2013.

11. Di Pasquale M, Rothstein JL, Palazzo JP. Pathologic features of Hashimoto's-associated papillary thyroid carcinomas. Hum Pathol. 2001 Jan; 32(1): 24-30.

12. Jakubowski W, Trzebińska A, Słapa RZ. Atlas badań ultrasonograficznych tarczycy. Roztoczańska Szkoła Ultrasonografii, Warszawa 2010, wyd 1.

13. Białek EJ, Jakubowski W. Obraz ultrasonograficzny w różnych chorobach tarczycy. W: Białek EJ, Jakubowski W, red. Diagnostyka ultrasonograficzna tarczycy, przytarczycy i węzłów chłonnych szyi. Wyd 1. Gdańsk: MAKmed; 2001: 68-73.

14. Polska Grupa do spraw Nowotworów Endokrynologicznych. Diagnostyka i leczenie raka tarczycy - rekomendacje polskie. Endokrynologia Polska. Tom 61; 5: 2010.

15. Jakubowski W, Trzebińska A, Słapa RZ. Atlas Badań ultrasonograficznych tarczycy. Roztoczańska Szkoła Ultrasonografii. Warszawa-Zamość 2010.

16. Ahn D, Heo SJ, Park JH, Kim JH, Sohn JH, Park JY i wsp. Clinical relationship between Hashimoto's thyroiditis and papillary thyroid cancer, Acta Oncol 2011; 50: 228-1234. doi: 10.3109/0284186X.2011.602109.

17. Kashima K, Yokoyama S, Noguchi S, Mukarami N, Yamashita H, Watanabe S i wsp. Chronic thyroiditis as a favorable prognostic factor in papillary thyroid carcinoma. Thyroid 1998; 8: 197-202. doi: 10.1089/ thy.1998.8.197.

18. Nikiforova MN,Nikiforov YE. Molecular genetics of thyroid cancer: implications for diagnosis, treatment and prognosis. Expert Rev Mol Diagn 2008; 8: 83-95. doi:https://doi.org/10.1586/14737159.8.1.83.

19. Sheils OM, O’Leary JJ, Uhlmann V, Lüttich K, Sweeney EC. RET/PTC-1 activation in Hashimoto thyroiditis, J Surg Pathol, 2000; 8: 185-189. doi: 10.1177/106689690000800305.

20. Wirtschafter A, Schmidt R, Rosen D, Kundu N, Santoro M, Fusco A, Multhaupt H, Atkins JP, Rosen MR, Keane WM, Rothstein JL. Expression of the RET/PTC fusion gene as a marker for papillary carcinoma in Hashimoto's thyroiditis. Laryngoscope, 1997; 107: 95-100.

21. Arif S, Blanes A, Diaz-Cano SJ. Hashimoto's thyroiditis shares features with early papillary thyroid carcinoma. Histopathology. 2002; 41:357362. doi: 10.1046/j.1365-2559.2002.01467.x.
22. Unger P, Ewart M, Wang BY, Gan L, Kohtz DS, Burstein DE. Expression of p63 in papillary thyroid carcinoma and in Hashimoto's thyroiditis: a pathobiologic link? Hum Pathol. 2003; 34: 764-769.

23. Burstein DE, Nagi C, Wang BY, Unger P. Immunohistochemical detection of p53 homolog p63 in solid cell nests, papillary thyroid carcinoma, and hashimoto's thyroiditis: A stem cell hypothesis of papillary carcinoma oncogenesis, Hum Pathol. 2004; 35: 465-473.

24. Uhliarova B, Hajtman A. Hashimoto's thyroiditis - an independent risk factor for papillary carcinoma, Braz J Otorhinolaryngol, $2018 \mathrm{Nov}-\mathrm{Dec}$; 84(6): 729-735. doi: 10.1016/j.bjorl.2017.08.012.

25.Zhang L, Li H, Ji QH, Zhu YX, Wang ZY, Wang Y, Huang CP, Shen Q, Li DS, Wu Y. The clinical features of papillary thyroid cancer in Hashimoto's thyroiditis patients from an area with a high prevalence of Hashimoto's disease. BMC Cancer. 2012; 12:610. doi:10.1186/14712407-12-610.

26. Konturek A, Barczynski M, Wierzchowski W, Stopa M, Nowak W. Coexistence of papillary thyroid cancer with Hashimoto thyroiditis. Langenbecks Arch Surg. 2013; 3: 389-94. doi: 10.1007/s00423-0121021-x.

27. Consorti F, Loponte M, Milazzo F, Potasso L, Antonaci A. Risk of malignancy from thyroid nodular disease as an element of clinical management of patients with Hashimoto's thyroiditis. Eur Surg Res. 2010; 3-4: 333-7. doi: 10.1159/000320954.

28. Matesa-Anic D, Matesa N, Dabelic N, Kusic Z. Coexistence of papillary carcinoma and Hashimoto's thyroiditis. Acta Clin Croat. 2009; 1: 9-12.

29. Anil C, Goksel S, Gursoy A. Hashimoto's thyroiditis is not associated with increased risk of thyroid cancer in patients with thyroid nodules: a single-center prospective study. Thyroid. 2010; 6: 601-6. doi: 10.1089/ thy.2009.0450.

30. Isik S, Gokay F, Ozuguz U, Topaloglu O, Tutuncu Y, Berker D, Guler $\mathrm{S}$. Comparison of the prevalence and sonographic features of thyroid nodules accompanying autoimmune thyroid diseases. Endokrynol Pol. 2010; 6: 658-64.

\section{Choroba Hashimoto jako czynnik ryzyka rozwoju raka brodawkowatego tarczycy}

\section{Streszczenie}

Wprowadzenie. Choroba Hashimoto, która jest najczęściej występującą chorobą autoimmunologiczną, już w 1955 roku została powiązana z najczęstszym nowotworem tarczycy - rakiem brodawkowatym tarczycy (PTC). Mimo upływu lat i wielu intensywnych badań naukowych nad związkiem tych dwóch chorób, nadal nie ustalono mechanizmu i tego, co leży u podłoża faktu, iż choroba Hashimoto predysponuje do wystąpienia PTC.

Cel pracy. Celem pracy jest podsumowanie aktualnego stanu wiedzy na temat mechanizmów, sprawiających, że HT może predysponować do rozwoju PTC oraz przedstawienie najnowszych badań klinicznych, które potwierdzają, że HT jest czynnikiem ryzyka PTC oraz opisują jej możliwy wpływ na przebieg choroby.

Skrócony opis stanu wiedzy. Praca odnosi się do mechanizmów zapalnego, immunologicznego i genetycznego, które mogą być istotnie związane z predyspozycją pacjentów z HT do rozwoju PTC. Ostatnie badania pokazały, że onkogen RET/PTC czy białko p63 mogą łączyć HT z rozwojem PTC. Niniejsza praca przedstawia również efekty badań klinicznych dotyczących porównania częstości występowania PTC u pacjentów z HT oraz u tych bez autoimmunologicznej choroby tarczycy.

Podsumowanie. Potrzeba kolejnych badań naukowych, dzięki którym dokładniej poznamy mechanizmy łączące HT i PTC. Należy zachować czujność onkologiczną podczas opieki nad pacjentem z HT, gdyż wiele badań naukowych potwierdza częstsze występowanie PTC u pacjentów dotkniętych autoimmunologicznym zapaleniem tarczycy. HT może mieć również istotny wpływ na przebieg nowotworu oraz jego rokowanie.

\section{Słowa kluczowe}

choroba Hashimoto, rak brodawkowaty tarczycy 